\title{
Foreign Debt Policies in South America, 1929-1945
}

\author{
Políticas de dívida externa na América do Sul, 1929-1945
}

MARCELO DE PAIVA ABREU*

RESUMO: Este artigo examina as semelhanças e contrastes das estratégias adotadas pelas grandes economias da América do Sul - Argentina, Brasil e Chile - ao lidar com os problemas levantados pela queda de suas receitas de exportação, juntamente com a interrupção quase completa do influxo de capital estrangeiro no país. final da década de 1920 e início da década de 1930. Também são consideradas as características do endividamento externo desses países no final da década de 1920 e as formas como o choque externo afetou sua balança de pagamentos entre 1928 e 29 a 1933 e 1934 . Seus processos de ajuste diferenciado, incluindo esquemas de ajuste de dívida adotados durante os anos 1930 e início dos anos 1940, são comparados. Os acordos de dívida permanente são descritos e discutidos. Por fim, considera os vínculos entre o desempenho de crescimento desses países e políticas diferenciadas de dívida externa.

PALAVRAS-CHAVE: Dívida externa; fluxos internacionais de capital; história econômica da América Latina.

ABSTRACT: This paper examines the similarities and contrasts of strategies adopted by the larger South American economies - Argentina, Brazil and Chile — in dealing with the problems raised by the fall of their export revenues coupled with the almost complete interruption of the inflow of foreign capital in the late 1920s and early 1930s. The characteristics of foreign indebtedness of these countries in the late 1920s and the ways the external shock affected their balance of payments from 1928-29 to 1933-34 are also considered. Their differentiated adjustment processes including debt adjustment schemes adopted during the 1930s and early 1940s are compared. Permanent debt settlements are described and discussed. Finally, it considers the links between growth performance of these countries and differentiated foreign debt policies.

KEYWORDS: Foreign debt; international capital flows; economic history of Latin America. JEL Classification: F34; N16.

\footnotetext{
* Departamento de Economia, Universidade Católica, Rio de Janeiro/RJ, Brasil. E-mail: mpabreu@econ. puc-rio.br.
} 


\section{INTRODUCTION}

Between the beginning of the depression in the late 1920's and the end of the Second World War for the first time in the history of the integrated world capital market it was necessary for many countries to adjust the requirements of foreign debt service to the actual capacity to generate foreign exchange on a permanent basis. In the developed world this affected mainly war reparations. In developing countries adjustment affected foreign portfolio capital which had been overlent particularly in the second half of the 1920s. In South America ${ }^{1}$ this adjustment was particularly severe and a main issue in the international economic policies of most countries. This paper examines the similarities and contrasts between strategies adopted by the larger South American economies in dealing with the problems raised by the fall of their export revenues coupled with the almost complete interruption of the inflow of foreign capital in the late 1920s and early 1930s.

The paper consists of five sections besides this introduction. The first section considers the characteristics of foreign indebtedness of these countries in the late 1920 s and how the external shock affected their balance of payments from 192829 to 1933-34, the most critical period in terms of foreign exchange scarcity. In the second section the differentiated adjustment of the three countries - Argentina, Brazil and Chile - is analysed. The debt adjustment schemes adopted in these countries during the 1930s and early 1940s are considered and compared in the third section. Permanent debt settlements are described and discussed in the fourth section. The fifth section includes material on the comparative growth performance of these countries, relates this to differentiated foreign debt policies and presents the conclusions.

\section{THE EXTERNAL SHOCK}

Argentinean terms of trade fell by about $45 \%$ between 1928 and 1933. Export volume fell by $15 \%$ in the same period so that capacity to import decreased almost $50 \%$. Exports decreased from $£ 211$ million pounds in 1928 to a low of $£ 84$ million pounds in 1933, more significantly — but at a slower rate - than in Brazil. The value of imports fell from $£ 169$ million in 1929 to $£ 61$ million in 1932 , somewhat less than in Brazil and much less than in Chile, but recovered at a slower pace than in Brazil as it remained below $£ 70$ million pounds until 1937.

The Argentinean public foreign debt amounted in 1930 to $£ 153.3$ million of which about $60 \%$ in US dollars and the rest mainly in sterling. ${ }^{2}$ Outstanding sterling

\footnotetext{
${ }^{1}$ As the Mexican foreign debt went into default in 1914 and remained so until 1942 when an agreement was reached on a permanent settlement, it was decided to exclude this country from the analysis.

${ }^{2}$ See Díaz-Alejandro (1970), p. 32. Holding of internal gold loans had been sharply reduced if compared to earlier years.
} 
bonds in 1914 had amounted to $£ 184.6$ million. ${ }^{3}$ Pre-great depression debt export ratios were rather low: around 0.9 in 1929. And not much above 2.0 in the worst years in the early 1930s. Debt service payments as a proportion of exports in 1929 were of only $6.2 \%$ and increased to a maximum of $15.6 \%$ in 1933 , much below the ratios for Brazil and Chile. ${ }^{4}$ These debt ratios underestimate the seriousness of the external shock in all South American countries as inflows of capital related to public loans which had been very considerable up to 1928 disappeared and the contribution of direct investment was not significant.

Brazilian exports fell from $£ 97.4$ million in 1928 to $£ 65.7$ million in 1930 and to a minimum of $£ 51.2$ million in 1932 . The terms of trade fell almost $45 \%$ from 1928 to 1931; this was partly compensated by an increase in export volumes so that the capacity to import remained roughly between 60 and $75 \%$ of its 1928 level for the rest of the decade. Imports fell to a minimum in 1931-32 of a third of their 1928 level of $£ 90$ million and remained until $193650 \%$ below this level, first as a result of the depressed level of economic activity then, after 1931, as a consequence of import controls and devaluation.

Brazilian public foreign debt had increased between 1913 and 1930 from $£ 152$ million to $£ 253$ million. In $191485 \%$ of the debt was in sterling bonds and the rest in French francs. British, American and French shares in 1930 were of roughly $65 \%, 30 \%$ and $5 \%$. Federal loans corresponded to $56 \%$, state and municipal loans to $30 \%$ and coffee valorization loans to $14 \%$ of total debt. The debt export ratio increased from 2.5 in 1929 to 5.5 in 1932 as a joint result of increased outstanding debt and fall of exports. ${ }^{5}$ Debt service as a proportion exports rose from $18.2 \%$ of total exports in 1928 to a maximum of almost $40 \%$ in 1931 before the funding loan renegotiations. It fell to $12-13 \%$ until the 1937 default and still more during the war. The world depression hit Chile much more seriously than either Argentina or Brazil. Exports fell from $£ 57$ million in 1929 to $£ 9.9$ million in 1932 . Not only terms of trade deteriorated more than in the other big South American countries — almost 50\% between 1929 and 1933 - but export volumes in 1932 were $70 \%$ below their 1929 level. Capacity to import in 1932-33 remained around $80 \%$ below the 1929 level as was the case of import volumes. ${ }^{6}$

Of the three big South American economies Chilean public foreign debt had increased the most since 1914: from $£ 42$ million pounds (of which 33.3 million pounds direct state loans and the rest state guaranteed loans) to $£ 92.3$ million pounds (of which $£ 60.8$ million direct, $£ 27.7$ million guaranteed and $£ 3.8$ million

\footnotetext{
${ }^{3}$ See Stone (1977), p. 706. This includes $£ 100$ millions of cedulas of the National Mortgage Bank.

${ }^{4}$ See Balboa (1972).

${ }^{5}$ It should be noted that while comparisons of country debt-export ratios may be useful if related to the same period in time this is not necessarily the case of comparisons over time as for instance between debt-export ratios in the 1930s and in the 1980s for a given country as average interest rates of pre-1930 loans were lower and maturities much longer.

${ }^{6}$ See Saes (1988) for economic policies as well as data on Chile in the 1930s.
} 
unguaranteed municipalities). All pre-war loans were in sterling while in 1930 the total was roughly evenly divided between sterling and US dollar loans. ${ }^{7}$ There was practically no outstanding sterling state-guaranteed loan as opposed to $47 \%$ of total US dollar loans. ${ }^{8}$ The debt-export ratio increased sharply as exports fell. From 1.5 in 1928-29 it increased to 2.7 in 1930, 4.4 in 1931 and reached a maximum of 11.5 in 1932. As exports recovered and the outstanding (defaulted) debt remained constant the ratio declined steadily to fall below 2.0 in 1937 . Debt service as a proportion of exports similarly rose from $14 \%$ in 1929 to $25 \%$ in $1930-31 .{ }^{9}$

\section{DIFFERENTIATED ADJUSTMENT: 1929-1933}

Argentina left the gold standard rather early as convertibility was suspended in December 1929. In contrast to her neighbours there was no default of national foreign debt and the record on provincial and municipalities was rather good in spite of some defaults in 1932 and 1933. In October 1931 an Exchange Control Commission was created to avoid further devaluation. After some initial fluctuation the rate of exchange was pegged. First priority in the distribution of foreign exchange was for government at all levels, second to essential imports, third to the remittances of public utility companies and immigrants. Then came, in order, personal travel remittances, non-essential imports and commercial arrears. The rules were at first applied on a non-discriminatory basis. This was soon to be altered as British bargaining power was exerted to impose preferential treatment for sterling claims under the notorious Roca-Runciman Treaty of 1933. A second stage of the exchange control was introduced in late 1933 reflecting the agreement as will be considered in the next section. ${ }^{10}$

The Brazilian initial answer to the crisis was extremely muddled as until sterling went off gold in 1931 there was hope that good behaviour was worthwhile and could mean a return to financial accommodation. After September 1931 new policies were introduced. A foreign exchange monopoly in charge of the Bank of Brazil, which posted a daily "official" foreign exchange rate, was instituted as well as exchange controls designed to ration scarce foreign exchange according to development needs based on criteria very similar to those introduced in Argentina. The foreign debt was renegotiated. In early September the Brazilian authorities decided to suspend sinking fund payments on all foreign loans, except the 1898 and 1914 Funding Loans resulting from previous major renegotiations and short-

\footnotetext{
${ }^{7}$ Besides about $3 \%$ of total debt denominated in Swiss francs.

${ }^{8}$ See Sanfuentes (n.d), passim. I have no data available on municipalities in 1914.

${ }^{9}$ See Ellsworth (1945), p. 10.

10 See Salera (1941, chapter III). Those interested in the study of how the contrasting international economic policies of the United Kingdom and the United States helped to explain different economic policies adopted in Argentina and Brazil can consult Abreu (1984).
} 
ly after to suspend interest payments related to all loans, with the exception of Funding Loans. This put pressure on creditors and an agreement was reached to last for three years. The Brazilian Government undertook to provide foreign exchange for the full service of the previous Funding Loans. Sinking fund payments concerning all other Brazilian loans were suspended and interest payments funded for three years through the issue of $5 \%$ funding bonds to be serviced normally. This arrangement worked to the advantage of bondholders holding British or French loans and to the detriment of American bondholders as the funding loans of 1898 and 1914 covered only the older British and French loans.

Chile defaulted its foreign debt payments in July 1931. At the same time a foreign exchange monopoly was introduced and exchange controls were created to be administered by the Central Bank. Exchange was distributed according to development priorities. Rules were introduced to assure that exporters of mineral products such as copper, nitrates, iodine and iron ore were exempted of export control but had to sell to the Central Bank foreign exchange equivalent to their production expenses in Chile.

In 1934 a mission was sent to South America by the United States State Department led by John H. Williams, of the Federal Reserve Bank of New York, later to become an influential Professor of Economics at Harvard. ${ }^{11}$ The report produced by Williams is probably the most balanced contemporary analytical effort concerning the exchange difficulties faced by most South American countries. ${ }^{12}$ It is in sharp contrast with similar efforts by other financial doctors, such as Otto Niemeyer, which resulted in totally unrealistic proposals for Brazil earlier in the decade. ${ }^{13} \mathrm{It}$ seemed clear to Williams that without minimizing the mistakes made by policymakers in these countries, "neither the origin of their exchange problem nor its solution is to be found primarily in acts or circumstances over which these countries have the principal control. A satisfactory general solution must depend upon world trade recovery and greater freedom of access to world markets".

Three methods according to Williams had been or were being employed to deal with exchange problems: (a) gold exports: this outflow, which was considerable in 1929-30, was of no avail as prices were falling throughout the world; (b) exchange devaluation: also of limited usefulness as, to work effectively, it depended on relatively stable prices in the outside world; devaluation, furthermore, threatened to produce internal inflation which would further impair the country's capacity to export as well as involve, for many countries, reduction of export proceeds as demand for agricultural products was inelastic and these countries controlled a sizeable share of the market; (c) exchange-control: whatever could be said in criticism

\footnotetext{
${ }^{11}$ Hull to Williams, 28.6.34, 810.5151 Williams Mission/2, US National Archives (NA): Record Group (RG) 59 .

${ }^{12}$ American Foreign Exchange Problems in Brazil, Argentine, Chile and Uruguay, Foreign Relations of the United States (FRUS) 1934, pp. 393-422.

${ }^{13}$ See Abreu (1974).
} 
of this method, it was introduced only in the summer of 1931 when the other two had been tried. The object of exchange control was to establish a fixed rate of exchange and to ration the supply of exchange created by exports so as to balance incoming and outgoing payments. In some countries, one important reason for the establishment of exchange control had been the need to assure a supply of foreign exchange for the government at a reasonable price so as to allow servicing of the foreign debt.

Williams thought that countries having commercial or financial interests in Latin America had to consider two alternative lines of policy. If the trade position was strong, that is, if more was bought than sold, there was no need to wait for a general solution and a partial solution could be forced whereby the foreign exchange created by the country imports should cover its own requirements. Such was the policy adopted, for instance, by Great Britain in Argentina. The other alternative was to wait and to assist in reaching a general solution. This policy was being pursued by the United States in spite of the strength of its trade position in Brazil and Chile. Past American policy had been based upon the recognition of the need for "triangular trade relations... if nations are to enjoy any degree of freedom to buy or sell particular products to best advantage". Bilateral trade, moreover, deprived the country operating an exchange control system of the power to reduce its imports according to some criterion of necessity.

\section{FOREIGN DEBT ADJUSTMENT IN THE 1930s AND 1940s}

The 1933 Argentinean exchange control new regulations reflected the terms of the Roca-Runciman Treaty. A dual exchange rate system was introduced, together with a sizeable further devaluation: an official (less devalued) rate coexisted with a free rate. The access of importers to the cheaper official rate was conditional on the importance of Argentinean exports to the country from which imports were to be purchased. Typically imports originating from Britain had a price edge of up to 15-20\% over, say, American goods, because of the importance of the British market for Argentinean exports. ${ }^{14}$ After 1933 terms of trade recovered steadily to reach in 1937 the 1928 peak level. The recovery of export volumes was less smooth but in the 1937 export boom the 1928 peak was also reached. Capacity to import in 1937 was roughly equivalent to that of pre-depression days while import volumes remained almost $30 \%$ below such peak values.

Argentina continued to service the foreign debt throughout the 1930s with only minor problems affecting non-national government debt. Old national government loans amounting to US\$246 million were withdrawn in 1936-37. A new loan of US\$ 128.5 million as well as domestic loans of roughly equivalent amount were

${ }^{14}$ See Salera (1941, chapter IV). The system of control was further changed in 1937-38. 
floated. An additional loan of US\$ 25 million was floated in 1938 . The new loans reduced interest rates from $6 \%$ of the original loans to $4-4.5 \% .^{15}$

In Brazil recovery of the balance payments position was slow: exports reached the 1928 level only in 1942 . In 1937 , the peak year in the 1930 s, total exports reached $£ 70.2$ million still only about $70 \%$ of their 1928 level. While terms of trade fell more or less continuously after 1934 this was more than compensated by a significant increase in export volumes so that average capacity to import in 193437 slightly increased to around $70 \%$ of its 1928 level. The negotiation of loans to thaw the financial and commercial arrears, the modest inflow of direct foreign investment, the laggard behaviour of imports in 1936 and bilateral trade deals contributed to ease the balance of payment position after 1934. An exchange regime abolishing the previous licensing procedures and relying exclusively on price effects was instituted in 1934-35.

In 1934, when the funding loan arrangement was expiring, it was decided by the Brazilian Government and the main creditors that negotiations should be opened with the objective of reaching an agreement which would involve higher total yearly payments as it would involve the resumption of service payments on loans other than those receiving full service under the provisions of the 1931 schemes. The proposed scheme's main feature was the division of all loans into seven grades according to their standing; the lower the grading, the lower the level of interest payments provided under the scheme (according to the percentage of interest contractually due); in the case of low-graded loans this percentage would increase in each of the four years covered by the scheme. Grades 1 (Funding Loans) and 2 (1930 Coffee Loan) for example, would receive full contractual interest payments while, at the end of the scale, grade 7 loans would receive nothing. Grade 1 would receive $100 \%$, and grade $2,50 \%$ of their contractual sinking funds, while the other loans would receive no sinking fund payments. ${ }^{16}$

The final agreement involved increased total payments: $£ 7.3$ million in the first year rising to $£ 9$ million in the fourth year as well as other minor concessions especially to the Americans who deeply resented the British-inspired scheme. An additional intermediate grade was created and the Brazilians introduced into the final agreement a provision which allowed the redemption of bonds at market prices in spite of the partial default. This was used especially in the case of the coffee loans. There were contemporary claims that Brazil would pay $£ 33.6$ million pounds in four years instead of the contractual $£ 90.7$ million, the real "gains" being $£ 57.1$ million pounds over four years. ${ }^{17}$ It is clear that Aranha was wrongly claiming as gains both actual reduction in interest payments and mere postponement of sinking fund payments. This issue will be further examined in section 4 below.

\footnotetext{
${ }^{15}$ See Jorgensen and Sachs (1988), pp. 42-45.

${ }^{16}$ See, for details, Abreu (1975).

17 This has been repeated by economic historians without adequate qualification. See, for instance, Bouças (1955).
} 
The 1937 US recession led to the deterioration of the Brazilian balance of payments as a steep increase in quarterly imports and a fall in export proceeds occurred from the third quarter of $1937 .{ }^{18}$ After the coup of November 1937 the Brazilian Government announced the suspension of all public foreign debt payments. Vargas argued that Brazil had been forced to default because it was impossible both to service the debt and pay for imports, which were essential for the re-equipment of the railway system and of the armed forces. The alternative course of entering into a new funding scheme was considered to be unacceptable, as it would increase the outstanding debt which was already considered to be out of proportion with the country's capacity to pay. ${ }^{19}$ Debt service was suspended until mid-1940. Negotiations which eventually started in September 1939 were the direct result of Aranha's - now Minister for Foreign Affairs - visit to the United States early in the year to negotiate a wide range of commercial and financial questions. Aranha assured Hull that Brazil would resume service related to American loans on the 1st of July 1939. This commitment, which exceeded Aranha's instructions, was strongly criticized in Brazil leading to Costa's veto concerning service resumption by the promised date. Aranha's undertaking, however, made it impossible to avoid opening negotiations. Protracted negotiations followed in Rio, the final provisional agreement being based on the last year of Aranha's plan. Total payments would rise from $£ 4$ million in the first year to $£ 4.3$ million in the fourth year.

In Chile in 1934-35 export volumes more than doubled in relation to the 1932 extremely low level, reaching $70 \%$ of its 1929 peak. Capacity to import thus markedly improved in spite of the slow recovery in the terms of trade which was reversed by the US recession of 1937. In early 1935 Law 5580 unilaterally regulated a renewal of public foreign debt payments. Debt service was to be related to the country's capacity to pay: a fund was created to be fed by the profits generated by Corporación de Ventas de Salitre as well as income tax on foreign copper companies. Half the fund's yearly revenue was to be used to pay interest and half for debt redemption at market prices. Interest payments at reduced levels were to be recognized by creditors as equivalent to the fulfillment of contractually defined interest obligations. Inclusion of creditors in the scheme was made conditional on their acceptance that no payments were due concerning interest arrears accumulated since 1931 and allowing their coupons to be stamped with the provisions of the new Chilean law. Yearly service fell from US\$ 40 million contractually due to US\$ 4 million.

Chilean bonds equivalent to US\$ 139.3 million were redeemed between 1935 and 1939 in return to cash payments of only US\$ 15.2 million. This affected almost exclusively dollar bonds. Redemption after 1939 was rather limited. ${ }^{20}$ Average interest rates rose from $0.5-0.8 \%$ in $1935-37$ to $2.9 \%$ in 1938 declining to around

\footnotetext{
${ }^{18}$ See NA RG 59, memo by Schmidt, 30.4.38, p. 17, 832.51/1301.

${ }^{19}$ Vargas (1938), vol. 5, pp. 26-28, speech of 10.11.37.

${ }^{20}$ Until 1943 it was not larger than US\$ 15 million.
} 
$1.5 \%$ in $1939-43 . .^{21}$ In 1940 and again in 1942 funds were diverted from the amortization account to other uses. Between 1935 and 1948 partial payments amounted to about $20 \%$ of contractual interest. ${ }^{22}$

\section{THE END OF A CYCLE: PERMANENT SETTLEMENT}

The accumulation of foreign exchange reserves during the Second World War made possible the negotiation of permanent settlements of the foreign debt in most Latin American countries. In Argentina, where there was the unique record of full payment of service in recent years, the question which posed itself was the repatriation of the debt. It became government policy to redeem foreign loans and by 1949 practically all loans had been bought at par. ${ }^{23}$

In Brazil a permanent agreement was reached towards the end of 1943. After protracted negotiations, all parties agreed to a settlement which would offer to the bondholders two options. Under option A, the original bonds would not be substituted by Federal bonds and yearly payments of initial $£ 7.7$ million (of which 5.2 million interest) would be made, on the assumption that all bondholders would choose it. Option B would involve an initial service of $£ 8.4$ million pounds yearly (of which 14.9 million interest) of the new $3.75 \%$ Federal bonds, as well as cash payments of $£ 22.9$ million pounds redeeming $£ 79$ million of outstanding debt at an average price of $29 \%$, also on the assumption that all bondholders would choose this option. ${ }^{24}$ Old grade 8 loans would be redeemed at $12 \%$ of the outstanding principal and the bulk of the interest arrears — those corresponding to the 1937- 40 default - would be liquidated at $25 \%$ of the 1940 agreement rates (that is, in the "best" case at $12.5 \%$ of contractual rate of interest)..$^{25}$ The settlement meant a partial abandonment of the principle that better secured loans (mainly British) should get priority in the event of a partial default.

What were the gains of debtors? On the one hand, there are what can be called postponement gains, which correspond to a postponement of payments bringing short run relief to the balance of payments position and are strictly equivalent to a forced loan. This is the case, for instance, when sinking fund payments are suspended but the debtor is still legally bound to pay in the future. On the other hand, there are permanent gains, which correspond to a real reduction of payments, no

\footnotetext{
${ }^{21}$ See Echevarri (1944), pp. 83 and ff. and Urzúa (1945), pp. 106 and ff.

22 See Jorgensen and Sachs (1988), p. 51 and ff

${ }^{23}$ See Jorgensen and Sachs (1988), pp. 45-46.

${ }^{24}$ Present values generated by options $\mathrm{A}$ and $\mathrm{B}$ were equivalent at $4 \%$ a year. At rates of discount higher than $4 \%$ alternative B would be more attractive. Risk entailed by option B moreover was lower as responsibility as the debts were contractually taken over by the Federal Government.

${ }^{25}$ See Decree Law 6019 of 23.11.43, Diário Oficial 25.11.43 for details on specific loans.
} 
legal obligation remaining to pay what has not been fully paid. This is the case when interest coupons are tendered by bondholders in return for an agreed reduction of contractual payment.

The importance of postponement gains is made clear by the fact that they correspond to $53 \%$ of total imports in 1932, declining to $22 \%$ in 1937 and rising to roughly $40 \%$ in $1938-39 .{ }^{26}$ From the point of view of availability of foreign exchange, the successive reductions of service payments were equivalent to an increase in exports and made possible the avoidance of further reduction in the level of imports and consequently higher rates of economic growth as will be discussed in the next section.

Brazilian permanent gains - besides those emailed by the reduction in principal and interest rates in 1943 - are the result of the addition of: actual reduction of interest payments corresponding to the 1934 and 1940 settlements; interest payments not paid on loans in chronic default redeemed at $12 \%$ in 1943; interest arrears which were not fully paid in 1943; gains related to the redemption of grade 8 loans at $12 \%$ and foregone interest on arrears in 1943 . These amounted to $£ 38.4$ million.

Gains related to the reduction in interest rates and principal brought about by the 1943 agreement amounted to $£ 111$ million pounds. The immediate gains related to cash payments under option B would have been of $£ 56.1$ million pounds if all bondholders had preferred this option which is a fair approximation of what really happened. The average interest rate on outstanding debt was reduced by $3.64 \%$ under option A and $2.38 \%$ under option B. Assessment of total Brazilian gains entailed by the agreement by computing the present values of each option as compared to contractual terms is made difficult by the lack of sufficiently detailed information on the different options. Supposing once again that all bondholders decided for option B, such gains - in terms of reduction of present value entailed by discounting the reduced yearly payments using the original average interest rate — amounted to $£ 54.9$ million pounds. One may think as if a total foreign debt of about $£ 220$ million pounds in 1943 had been reduced due to principal and interest rate reduction to 111 million pounds. ${ }^{27}$ The importance of the foreign debt issue was much reduced in the postwar period especially so as blocked sterling balances were used to some repatriation of outstanding sterling bonds in 1950 as Brazil took fright due to rumors of a partial British default circulated. ${ }^{28}$

\footnotetext{
${ }^{26}$ Straight comparisons between postponement gains and the level of imports are, however, distorted by the accumulation of commercial arrears during the period.

${ }^{27}$ See Abreu (1988), p passim.

${ }^{28}$ It must be stressed that these computations of losses take contractual service as reference. Long-term assessment of gains and losses entailed by debt renegotiations needs to take into account the risk related to such loans since the early 19th century. In the case of Brazil if account is taken of all payments and receipts related to the pre-1930 foreign debt from 1824 to 1987 the actual rate of return is about double the rate of return on British consols, even taking defaults and renegotiations into account. It is of course true that latecomers - mainly in the US market - fared much worse than others, but on average
} 
Due to the World Bank refusal to approve a loan in 1946 Chile entered in negotiations with the bondholders' associations and reached agreement in 1948 on a conversion of all outstanding bonds into 46-year Republic bonds bearing $1.5 \%$ interest until 1948, rising to $3 \%$ after 1953 . Bondholders who had not accepted the terms of the 1935 Law were to receive all compensation previously offered in the form of non-interest bearing script redeemable over a period of ten years. ${ }^{29}$

Comparison between the Brazilian and Chilean settlements of the foreign debt question indicates that Chile managed to pay considerably less than Brazil: interest arrears were not paid under the Chilean 1935 Law; the Chilean average debt redemption price - affecting a similar proportion of total debt - was of roughly $10 \%$ of face values as compared to Brazil's $29 \%$; the 1948 Republic bonds interest rates - of $1.5 \%$ until 1954 then of $3 \%$ - were below the $3.75 \%$ agreed by Brazil.

\section{THE GROWTH-DEBT TRADE-OFF}

Argentinean GDP fell 14\% between 1929 and 1932, an intermediate performance if compared to Chile and Brazil. By 1939 GDP was 17\% above its 1929 level, having increased at the average yearly rate of $1.8 \%$, only $0.1 \%$ above population growth. ${ }^{30}$ Chilean GDP fell 33\% between 1929 and 1932. It then recovered to reach a level $4 \%$ above 1929 in $1938 .{ }^{31}$ The average rate of growth in these 9 years was $0.4 \%$ while population was growing $1.6 \%$ yearly. Brazil had a far better performance. The fall in GDP was limited - only $6.1 \%$ between 1929 and 1931and recovery was extremely fast. By 1939 GDP was 52\% above that of 1929, having increased at the yearly average rate of $4.3 \%$ with the population growing at rates similar to those in the other two countries.

All three economies faced severe foreign exchange constraints. Their capacity to gain access to foreign exchange through the ordinary channels of export expansion, government loans or foreign direct investment had been either eliminated or curtailed by the depression in the world economy. It is not surprising that adjustment should be sought in relation to foreign debt service payments as released foreign exchange could be used to increase imports and consequently investment and prospective rates of growth.

Brazilian bonds provided a good return to investors. See Abreu (1999) for a systematic assessment of Brazil's behaviour as a debtor based on comparative rates of return with some treatment of volatility of rates of return and risk. Literature on foreign debt, by concentrating either on dollar-denominated bonds floated in the 1920s (Jorgensen and Sachs (1988) and Eichengreen and Portes (1989)), provides a somewhat distorted picture of Brazilian experience as a debtor country.

${ }^{29}$ See Jorgensen and Sachs (1988), pp. 54-55.

${ }^{30}$ See for population data Díaz-Alejandro (1970, p. 421), Saes (1988) and IBGE (1988), and for GDP data Thorp (1984).

${ }^{31}$ In 1939 GDP decreased by $2.9 \%$. 
If Argentina had adopted a scheme of debt service reduction equivalent to the Brazilian 1934 agreement which reduced service to one third its contractual level and used all freed foreign exchange to import capital goods GDP would have increased at an yearly rate $0.7 \%$ higher than it actually did..$^{32}$ A lower bound is provided by the estimate generated based on the assumption that freed exchange would be distributed exactly in the same way as total imports were distributed in the mid-1930s, that is capital goods would correspond to only $20 \%$ of freed exchange. The consequent increase in the yearly GDP growth rate would be a negligible $0.15 \%$. An intermediate scenario based on the more realistic assumption that $50 \%$ of the freed exchange would be used to import capital goods would generate an increase in the yearly rate of $0.4 \%$. It did not cost much to be well behaved.

Similar computations for Brazil are even more fragile given the paucity of national accounts data. Under the heroic assumption that all freed foreign exchange would be used to import capital goods by maintaining payments under the 3rd·Funding Loan and the Aranha scheme in 1932-37 Brazil reduced its yearly growth rate by $0.7-1.0 \%$. The lack of realism of such an assumption was actually demonstrated by the impact on Brazilian imports of the 1937 default as much of the diverted exchange was used to pay imports of consumer goods. ${ }^{33}$ More realistic assumptions allowing for $50 \%$ of freed exchange being transformed into capital goods would reduce such foregone yearly rates of growth to the $0.1-0.3 \%$ region. ${ }^{34}$ On the other hand to pay full service would have reduced growth by something around $2.5 \%$ a year. It would cost a lot to be well behaved. In the Chilean case good behaviour would be even more expensive in terms of foregone growth.

The great depression provoked a highly differentiated response of the larger South American economies concerning the foreign debt. In one extreme, Argentina strictly observed the contractual terms of its national government debt and only in a limited number of cases there were delays concerning the service of provincial and municipal debt. In the other extreme, Chile, facing a much more serious exchange crisis, defaulted then paid very little service while at the same time redeeming a substantial part of its foreign debt at extremely low prices. Brazil provides the intermediate case, combining reduction of service through refinancing and service reduction with default in the late 1930s.

The Argentinean decision to pay was not very costly in terms of foregone growth simply because the country was much less indebted than its neighbours. While the differences between policies adopted in each country can be partly ascribed to actual economic conditions and domestic policy responses, strategies concerning the foreign debt are also partly explained by the political balance be-

\footnotetext{
32 Supposing that imported capital goods correspond to $50 \%$ of fixed capital formation and a capital output ratio of 4. See Díaz-Alejandro (1970), p. 330.

${ }^{33}$ See Abreu (1978).

${ }^{34}$ It is not worthwhile to examine the case of Chile as its reduction of debt service was practically equivalent to a total default.
} 
tween different pressure groups. In Argentina under the Concordancia government it is difficult to think of alternative policies being adopted given the powerful bargaining position of British interests and its emphasis on financial objectives as well as the accommodating mood of Argentinean governments in the 1930-43 period. ${ }^{35}$ Good behaviour of course made sense if the objective was to return to financial markets. But then it is difficult to understand the extremely anti-American stand even of Argentinean conservatives during the Second World War, a position which was aggravated after the rise of Perón. Argentinean policies seem to have been based on inadequate assessment of the long-term balance payments prospects of the country. After redeeming all its foreign debt in the 1940s, because interest rates were higher than those prevailing in the domestic market, Argentina faced from the early 1950s a permanent scarcity of foreign exchange in a world economy where Britain, the old partner, was in full decline, and the US had ample reasons to resent Argentinean animosity in the past. Brazil and Chile with much worse records concerning debt payment were much better treated by the US. This was specially the case of Brazil in the early war period and was the result partly of the relatively low priority of the debt question in the list of issues of US interest and partly of the Brazilian strategic importance both for the conduct of war in North Africa and as the main counterweight to pro-Axis Argentina in South America. Argentina's good financial behaviour seemed in the eyes of lenders more than compensated by its stand in international affairs and the economic policies under the first Perón government so that it did not provide a basis for a differentiated treatment in world financial markets in the following years.

\section{REFERENCES}

ABREU, M. de P., “A Missão Niemeyer”, Revista de Administração de Empresas, São Paulo, 14 (4), August 1974.

ABREU, M. de P., "Brazilian Public Foreign Debt Policy, 1931-1943” Brazilian Economic Studies, 4, 1978.

ABREU, M. de P., "Argentina and Brazil during the 1930s: The Impact of British and American International Economic Policies" in R. Thorp (ed.), Latin America in the 1930s. The Role of the Periphery in World Crisis, Macmillan, London, 1984.

ABREU, M. de P., “On the Memory of Bankers: Brazilian Foreign Debt, 1824- 1943”, Political Economy, 4(1), 1988.

ABREU, M. de P., “Brasil, 1824-1957: bom ou mau pagador?”, Texto para Discussão 403, Departamento de Economia, PUC-Rio, 1999.

BALBOA, M. “La Evolución del Balance de Pagos de la República Argentina, 1911-1950”, Desarollo Economico, 45, April 1972.

BOUÇAS, V. F., Finanças do Brasil. Dívida Externa 1824-1945, Ministério da Fazenda , Rio de Janeiro, 1955.

\footnotetext{
${ }^{35}$ See Abreu (1984) in Thorp (1984) for a comparison of the foreign economic policies of Argentina and Brazil and an attempt to explain contrasts based on different trade structures.
} 
DIAZ-ALEJANDRO, C. Essays on the Economic History of the Argentine Republic, Yale University Press, New Haven, 1970.

ECHEVARRI, J.C. "Nuestra Deuda Externa. Suspensión y reanudación de sus servicios” Memoria de Prueba para optar al grado de Licenciado en la Facultad de Ciencias Jurídicas y Sociales de la Universidad de Chile, Santiago, 1944.

EICHENGREEN, B. and R. PORTES, “After the Deluge: Default, Negotiation, and Readjustment during the Interwar Years" in B. Eichengreen and P.H. Lindert (eds.), The International Debt Crisis in Historical Perspective, Cambridge (Mass.), MIT Press, 1989.

ELLSWORTH, P.T. Chile. An Economy in Transition, The Macmillan Company, London, 1945.

Foreign Relations of the United States 1934, volume V, The American Republics, Government Printing Office, Washington, D.C., 1955.

IBGE, Estatísticas Históricas do Brasil. Séries Econômicas, Demográficas e Sociais de 1550 a 1985, Rio de Janeiro, 1987.

JORGENSEN, E. and J. SACHS, "Default and renegotiation of Latin American Foreign Bonds in the Interwar Period”, NBER Working Paper 2636, Cambridge (Mass.), June 1988

SAES CONTRERAS, J. S. "La Economia Chilena en la Decada del Treinta: Ruptura, Continuidad y Cambio", M.A. dissertation, Department of Economics, Catholic University of Rio de Janeiro, 1988.

SALERA, V. Exchange Control and the Argentine Market, Columbia UP, New York, 1941.

SANFUENTES V. A. "La Deuda Externa de Chile entre 1818 y 1935", mimeo, Universidad de Chile, Santiago, n.d.

STONE, I. "British Direct and Portfolio Investment in Latin America before 1914", Journal of Economic History, XXXVII (3), September, 1977.

THORP, R. (ed.), Latin America in the 1930s. The Role of the Periphery in World Crisis, Macmillan, Londres, 1984.

URZÚA, A. Ferrada "Historia Comentada de la Deuda Externa de Chile 1810-1945", Memoria de Prueba, Imprenta Casa Hogar San Pancracio, Santiago, 1945.

VARGAS, G. A Nova Política do Brasil, vol. V, José Olympio, Rio de Janeiro, 1938.

VERA, R., "História de la Deuda Externa de Chile", Memória de Prueba, Instituto Roma, Santiago, 1942. 